pauze te scheppen en dat een intern, op betalingsbalansevenwicht gericht beleid het eigenlijke werk moet doen.

Dr. C. D. JoNGMAN

\title{
UIT DE ECONOMIST VAN 1865
}

Onze natie heeft van de zijde harer Germaansche broeders over 't algemeen meer scheeve beoordeeling, dan billijke en juiste waardering ondervonden. De Duitscher, die zich verwaardigde over Holland en de Hollandsche toestanden te schrijven, was maar zelden voldoende ingelicht; hij rekende zich ontslagen van de moeite om kennis door nasporing te verkrijgen. Oppervlakkigheid en vooringenomenheid kenmerkten zijne uitspraken, en vaak nam fantasie de plaats in, die aan onderzoek toekwam. Het geschetste beeld was carricatuur, geen portret.

Sedert de laatste jaren echter is er in de wijze waarop. Duitschers over Holland oordeelen, een verandering ten goede op te merken. Menig vooroordeel, dat de volken van elkaâr verwijderde, is gevallen voor den invloed van een druk en levendig verkeer. De onverschilligheid voor Nederland heeft in Duitschland opgehouden. Er openbaart zich bij de naburen een streven om met ons land, onze geschiedenis en onzen volksaard bekend te worden; zij willen niet langer vreemd blijven aan hetgeen op wetenschappelijk gebied ten onzent voorvalt. Het boek van Laspeyres is een merkwaardig teeken van die toenemende belangstelling; en dat uit Duitschland een poging werd uitgelokt om een leemte in onze eigene historisch-economische literatuur aan te vullen, is een verschijnsel, dat onze aandacht in hooge mate verdient. $(. \ldots \ldots \ldots)$

Het veld der geschiedenis onzer economische ontwikkeling ligt nog grootendeels onbearbeid. Zelfs over onze handelspolitiek is ter naauwernood iets bruikbaars geleverd. (...) Wat tot dusverre over sommige voor de staathuishoudkunde belangrijke personen en gebeurtenissen het licht zag, vergoedt het gemis niet eener geschiedenis van het ontstaan, den voortgang en den invloed der economische begrippen in ons vaderland.

Onschatbare bouwstoffen voor het bewerken van die geschiedenis zijn door Laspeyres in zijn aan het hoofd van dit opstel genoemde prijsverhandeling te zamen gebragt.

Mr. F. J. Baert, Een blik op de Economische ontwikkeling van ons vaderland in de XVIIIe en XVIIIe eeure. (Bespreking van E. Laspeyres, Geschichte der volkswirthschaftlichen Anschauungen der Niederländer und ihrer Litteratur zur Zeit der Republik, Leipzig 1863; Bijblad, blz. 1 en 2). 